\title{
DR Congo Debt Sustainability: A Quinquennial Assessment
}

\author{
Dieu-Merci Akonkwa Nyamuhirwa ${ }^{1,}$, , Jean-Baptiste Ntagoma Kushinganine ${ }^{2}$ \\ ${ }^{1}$ Center of Expertise in Mining Sector Management (CEGEMI), Faculty of Economics, Catholic University of Bukavu (UCB), Bukavu, DR \\ Congo \\ ${ }^{2}$ Faculty of Economics, Catholic University of Bukavu (UCB), Bukavu, DR Congo
}

Email address:

akonkwa.nyamuhirwa@ucbukavu.ac.cd (Dieu-MerciA. N.),jbntagoma@yahoo.fr (Jean-BaptisteN. K.)

${ }^{*}$ Corresponding author

\section{To cite this article:}

Dieu-Merci Akonkwa Nyamuhirwa, Jean-Baptiste Ntagoma Kushinganine. DR Congo Debt Sustainability: A Quinquennial Assessment. International Journal of Science, Technology and Society. Vol. 7, No. 1, 2019, pp. 8-13. doi: 10.11648/j.ijsts.20190701.12

Received: December 28, 2018; Accepted: February 11, 2019; Published: March 1, 2019

\begin{abstract}
The sustainability of the debt is an important pillar of a healthy economy, especially as it illustrates a country's ability to meet its debt obligations without recourse to debt relief or arrears. This paper analyzes the sustainability of DR Congolese public debt. It starts from the origin of the debt through the analysis of the situation after the completion point of the PPTE initiative to finally analyze the sustainability of the public debt and the risks it faces. Globally, it was noted that without the PPTE initiative, the DRC's external debt indicators would have exceeded the applicable thresholds: $30 \%$ of GDP, $100 \%$ of exports and $200 \%$ of revenues, but once they reach the completion point these ratios fell below the applicable thresholds: $24.4 \%$ of GDP, $42 \%$ of exports, and $124.3 \%$ of revenues.
\end{abstract}

Keywords: Sustainability, Public Debt, Sustainability of Public Debt

\section{Introduction}

The sustainability of the debt is a subject that shakes and animates several authorities in the world. It is an important pillar of a healthy economy, especially as it illustrates a country's ability to meet its debt obligations without recourse to debt relief or arrears.

In the eighties years many developing countries experienced unsustainable public debt situations, although this is not the first time such a situation has been observed in the history of nations. This has strengthened and nourished the need for intellectuals and organizations both national and international to analyze each fiscal year, or each year as is the case of DRC, the sustainability of the public debt. It is in this context that this work finds its interest and seeks to analyze the dynamics, the composition, the sustainability and the risk of the DR Congolese public debt.

He thus addresses in turn the origin of Congolese RD debt (section 1); the initiative PPTE and completion point (section 2 ); the analysis of the public debt portfolio (section 3); the sustainability of the public debt (section 4) and finally the risks related to the debt portfolio (section 5).

\section{Origin of Congolese Debt}

DR Congolese debt is not new, it goes back since the colonial period. Already in 1890 , to cope with many financial difficulties, King Leopold II, had persuaded the Belgian Parliament to grant him a loan of 25 million Belgian francs and in exchange, he would engage in his will, bequeath the Congo to Belgium, which was to be transferred to the Belgian Congo after independence. However, the origin of Congolese debt in terms of viability dates back to the 1970s, specifically between 1973 and 1975. The country's outstanding external debt at the end of 1972 was \$ 544 million or $25 \%$ of GDP and a ratio of debt / export service of $5 \%$ far below the threshold of necessary debt sustainability. In 1975 , the stock of debt rose to $\$ 2,915$ million, equivalent to $90 \%$ of GDP and a debt service / export ratio of $10 \%$. The first sustainability indicator thus proves a situation of unsustainability.

With the growth of Western interest rates increased by a predatory government, in 1976 the debt will then be estimated at $\$ 3$ billion and will continue to accumulate until reaching \$ 13 billion in 2000 . With the snowball effect 
observed, between 1976 and 2002 a number of rescheduling will be negotiated to allow the country to have more time to cope. There will be a total of 9 rescheduling and if we extend to the completion point of the Heavily Indebted Poor Countries initiative in July 2010, we will have 13 rescheduling in all. The bulk of the DRC's debt has been canceled through this initiative, which we discuss in the next section.

\section{PPTE Initiative and Completion Point}

Given the unsustainable debt in most poor countries of the world during the 1980s, PPTE initiative was launched in 1996 by the World Bank and the IMF and enhanced in 1999 with the aim of alleviating the excessive burden the external debt of the latter including DR Congo with a portfolio of $\$ 13,879.6$ million in 2001. As can be seen in Figure 1 the major creditor of the DRC is the Paris Club with $70.50 \%$ of claims against only $24.2 \%$ of claims held by multilateral creditors, the highest of which are those of the group of the
World Bank (9.8\%) and AfDB (8.5\%).

In the chaotic economic and political context, in 2001 the country already had arrears of approximately \$ 10925.2 million, $82 \%$ of which went to the Paris club, of which twothirds went to five club countries (United States, France, Belgium, Germany and Italy). In the face of considerable arrears, the country had to regularize its financial situation in order to benefit from borrowing opportunities for its reconstruction. Only in 2002 will the restructuring plan begin in two phases through the PPTE Initiative. The first phase, which began in June-July 2002, was to pay the arrears of the Congolese arrears to the IMF and the World Bank. In this phase, it was a question of replacing old debts with new ones but at concessional interest rates. The second phase began in September 2002, it was to restructure the Congolese debt owed to creditors fourteen countries gathered in the Paris Club estimated at $\$ 10.3$ billion, of which nearly $90 \%$ are accumulated arrears since the last agreement between the Paris Club and Zaire de Mobutu in 1989.

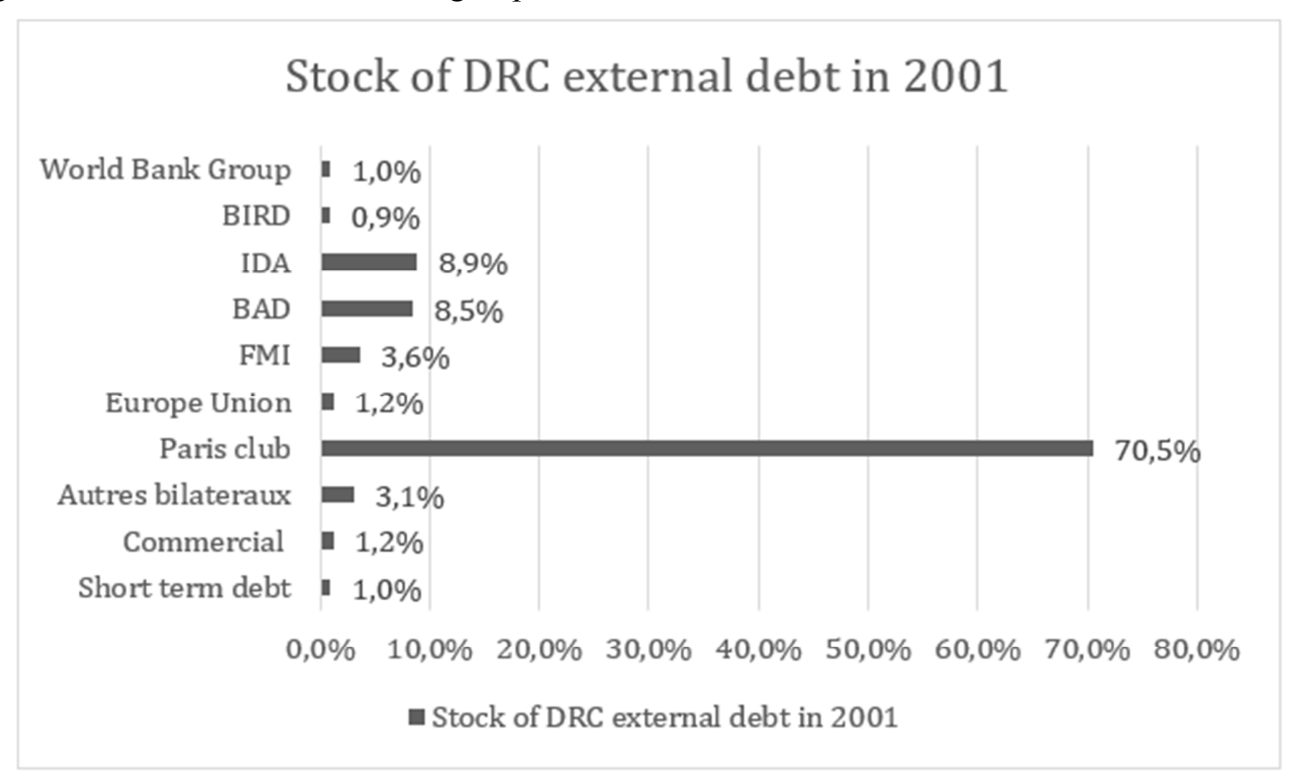

Figure 1. External debt in 2001.

Phase two will lead, on the one hand, to a debt cancellation of $\$ 4.6$ billion and a reduction of about $67 \%$ of the country's debt services and, on the other hand, to a rescheduling of nearly $4.3 \%$ other billions. Once the completion point reached, in July 2010, many analyzes were conducted in order to highlight the DRC's gain from this initiative but also to analyze the sustainability of the DRC's debt. First, it was noted that without the PPTE initiative, the DRC's external debt indicators would have exceeded the applicable thresholds: $30 \%$ of GDP, $100 \%$ of exports and $200 \%$ of revenues, but once they reach the completion point in July 2010 these ratios fell below the applicable thresholds: $24.4 \%$ of GDP, $42 \%$ of exports, and $124.3 \%$ of revenues. Second, the update of the debt sustainability analysis conducted in 2010 showed that the country remains exposed to the risk of debt distress. In the reference scenario, the NPV debt-to-GDP ratio exceeds, in the medium term, the $30 \%$ reference threshold. But if the country has made the most of the profit, does the country's external debt remain sustainable after the completion point? this is the question we are trying to answer in the following lines, but before that we analyze the dynamics and the composition of the public debt since 2010 .

\section{Public Debt Portfolio Since 2010}

The purpose of this analysis is to highlight, on the one hand, the trend of the public debt portfolio over seven years, and on the other hand to highlight the trend of its domestic and external components and a distribution of the portfolio according to the private and public component. We use DGDP statistics for this purpose. 


\subsection{Dynamics and Composition of the Public Debt}

Reading Figure 2 shows that overall the DRC's debt has been maintained in the $\$ 6000$ to $\$ 7000$ million tranche after the completion point. However, there are some peaks especially for the year 2013 with an increase of $5.23 \%$ mainly related to the flow of disbursements of 2012 and 2013 of the Sicomines loan and for the year 2017 with an increase of $8.26 \%$ imputed to the certification of new domestic debt records, in addition to some disbursements of external loans. If there are some peaks during the two periods, the public debt knows a continuous decline between the year 2013 and 2016. One can note a fall of $4.26 \%$ between the year 2013 and 2014 then $2.21 \%$ between 2014 and 2015 and $4.19 \%$ between 2015 and 2016. It should be kept in mind that these are the periods during which the country achieves good economic performance.

When we analyze the two components of the public debt, on the one hand domestic and foreign debt, there is a slight stability of domestic debt from 2011 to 2016. On the other hand, 2017 is characterized by a

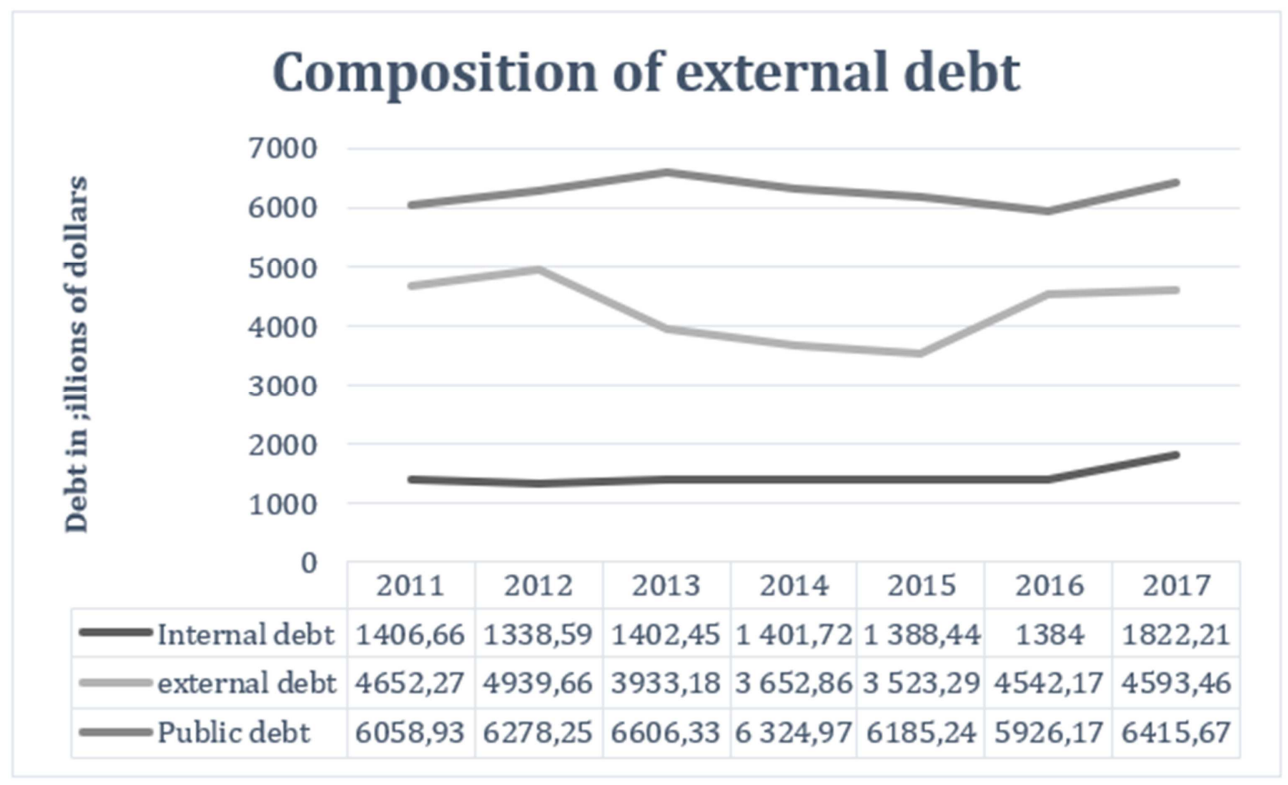

Figure 2. Dynamics of debt since 2011.

Increase in the domestic public debt and especially in its social debt component as shown in Figure 3. Starting with the increase in domestic debt, this is mainly due to a considerable increase in budget arrears grouped in social debts. with a transition from $11.16 \%$ of domestic debt to
$38.79 \%$. It should also be noted that the other groups experienced a percentage decline except financial debt, the percentage of which went from $3.04 \%$ to $4.3 \%$ of the debt stock.

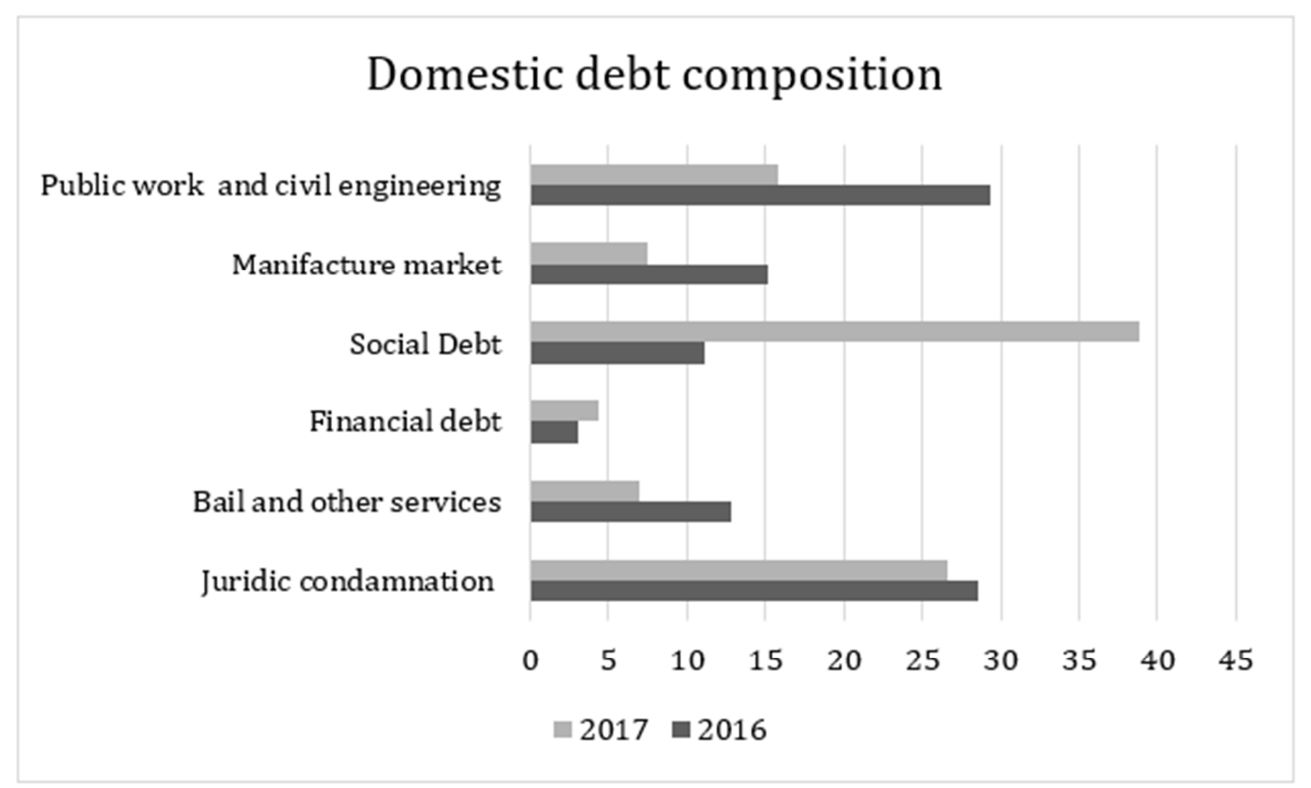

Figure 3. Composition of domestic debt 
With regard to the external debt, Figure 2 shows firstly an increase between 2011 and 2012, then a decline over the next three years $(2013,2014$ and 2015) and then an upward trend between 2015 and 2017. To understand the source of this decline on the one hand and this increase on the other hand analyze the composition of the external debt portfolio.

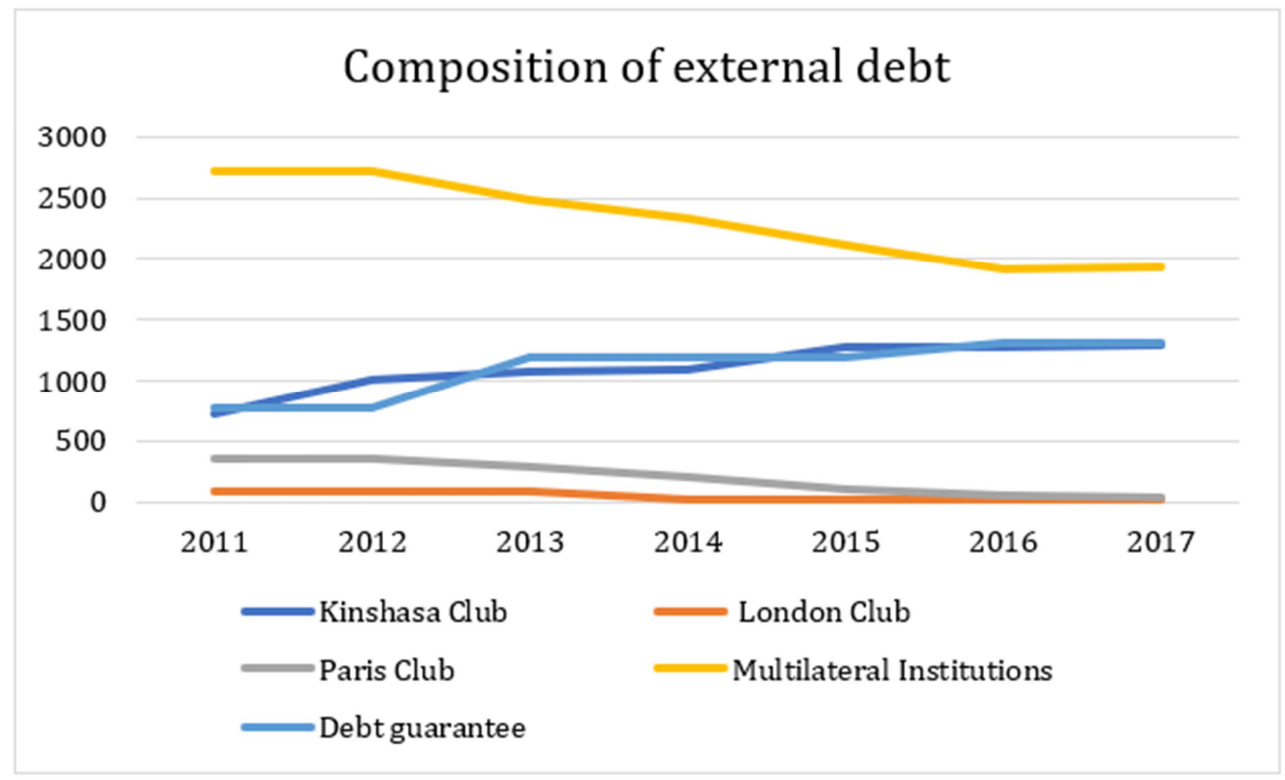

Figure 4. Composition of external debt.

Reading Figure 4 above shows a continued growth in claims to the Kinshasa club and a combined increase in the slight stagnation of the guaranteed debt for the first two years 2011 to 2012 and 2013 until 2015 and at the end of 2016 until 2017. Overall there is a strong downward trend in the claims of the Paris Club (\$ 346.46 million in 2011 up to $\$ 38.47$ million in 2017 receivables). This decrease would initially explain the decline in external debt after the completion point of the PPTE Initiative. However, this category is not the only one to register a decline. Accounts receivable from multilateral institutions also decrease by almost half their 2011 volume, from \$ 2721.37 million in 2011 to $\$ 1926.14$ million. On the other hand, the rise in the external debt observed at the beginning of 2015 in Figure 2 is globally explained by an increase in the debt volume of two components, including that of the Kinshasa Club, as well as that of the guaranteed debt.

\subsection{Distribution of Debt by Private and Public Sector}

If the overall public debt is made up of internal and external debt, it may still be distributed according to the sector of origin. Thus, on the one hand, private creditors will have images of banks, households, and so on. who buy the bonds and other securities issued by the State and on the other hand the public creditors such as the club of Paris which includes within it a number of the countries with capacity of financing. This section seeks to see where the Congolese state got the bulk of its loans.
Figures 5 and 6 below show that until 2017 the bulk of DR Congo's borrowing comes from the public sector with $69.06 \%$ of the external debt and only $30.94 \%$ of the external debt comes from private sector. The breakdown of the private sector shows that about $27.8 \%$ of credit claims are held by commercial banks compared to only $3.1 \%$ held by suppliers. However, we can generally see that after 2010 , private claims have a tendency to increase from $22.56 \%$ to $30.94 \%$ between 2011 and 2017 . With regard to the volume of external debt coming from the public sector, notes a downward trend in the DRC's debt to multilateral creditors but an increase in bilateral debt. In 2011 the share of multilateral debt was $58.5 \%$ against $18.95 \%$ of bilateral debt but in 2017 their respective shares rose to 41.93 and 27.13 .

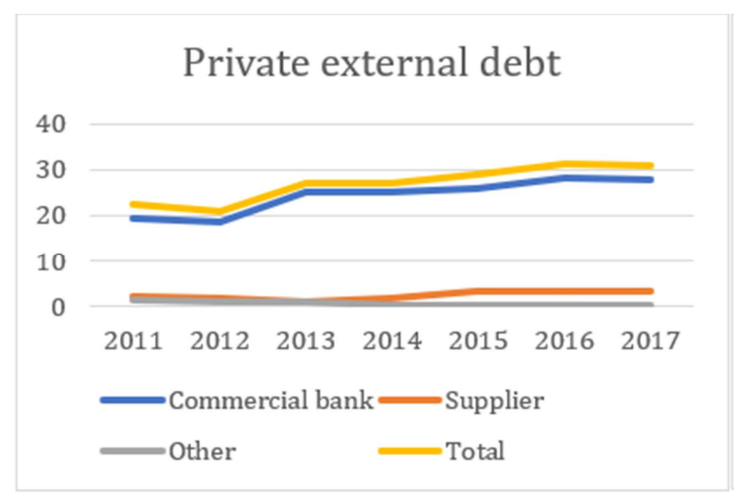

Figure 5. Private sector. 


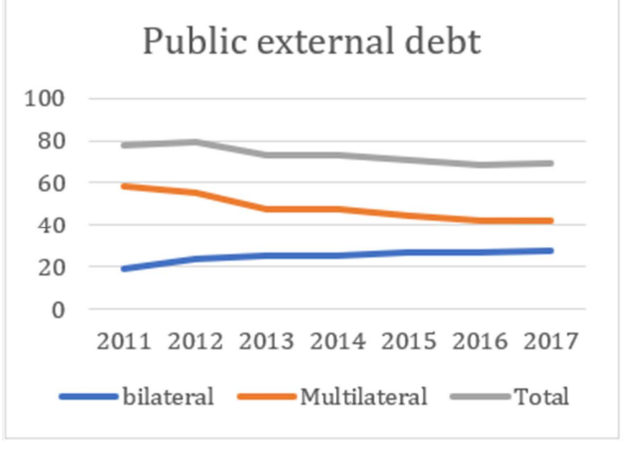

Figure 6. Public sector.

In sum, the bulk of Congo's borrowing does not come from multilateral institutions but rather from bilateral institutions, commercial banks, suppliers and other creditors with an overall share of $58.07 \%$. But if so, does this situation guarantee the sustainability of the public debt? does it make public debt less risky? these are the questions to which the following points provide answers.

\section{Debt Sustainability After Completion Point of I-PPTE}

This section analyzes the debt sustainability of the DRC on the basis of commonly used indicators including the NPV debt-to-GDP ratio, the NPV debt-to-exports ratio and the debt service-to-exports ratio. To understand the trend of these indicators we start one year before the completion point and then we take the situation in 2010 and end after the completion point of I-PPTE until 2015. The table below shows the trend.

Table 1. Debt sustainability analysis.

\begin{tabular}{|c|c|c|c|c|c|c|c|c|}
\hline & Threshold (\%) & 2009 & 2010 & 2011 & 2012 & 2013 & 2014 & 2015 \\
\hline NPV Debt / GDP & 30 & 121,75 & 20 & 20 & 19,4 & 13,5 & 15,2 & 11 \\
\hline NPV Debt / Exports & 100 & 303,8 & 65 & 42 & 43 & 44 & 44 & 34 \\
\hline NPV Debt / Budget & 200 & 647,71 & 138 & 150 & 110 & 124 & & \\
\hline Debt / Export Service & 15 & 20,01 & 5 & 2 & 2 & 2 & 1,5 & 1,7 \\
\hline Debt / Budget Service & 25 & 42,79 & 10 & 5 & 4,6 & 4,6 & 4 & 4,1 \\
\hline
\end{tabular}

The above table shows first that before the completion point of I-PPTE the Congolese State's debt was globally unsustainable with more than four times the required threshold of the NPV debt-to-GDP ratio of $121,75 \%$, more than triple the required NPV debt-to-exports ratio threshold of $303.8 \%$; a budget financed mainly by loans with a NPV Debt / Budget ratio equal to $647.71 \%$; and the same observation for the other ratios. What is interesting though is that after the completion point of I-PPTE the debt situation remains viable. We can observe a change from the NPV Debt / GDP ratio of $20 \%$ in 2010 to $11 \%$ in 2015 , a decrease of $9 \%$; the NPV Debt / Exports ratio decreased by $31 \%$ between 2010 and 2015; the NPV Debt / Budget ratio decreased by $14 \%$ between 2010 and 2013; the Debt Service / Exports ratio decreased by $3.3 \%$ and a decrease of $5.9 \%$ in the case of the Debt Service / Budget ratio.

This state of affairs is mainly due to good economic performance recorded during this period. Following the update of the Debt Sustainability Analysis (DSA) carried out in May 2017 with debt data at the end of 2016, DR Congo is classified as a country at moderate risk of over-indebtedness, and this for two reasons including:

1. First, no threshold is exceeded in the analyzed scenarios;

2. Second, some exceedances are observed in sensitivity tests. Hence the moderate qualifier.

However, the sensitivity analysis conducted on both public debt has revealed that Congo's public debt portfolio remains vulnerable to exports shocks. What about the risk she faces? The next section presents the DRC's debt risk analysis.

\section{Risk Analysis Related to the Public Debt Portfolio}

Three types of risks are taken into account in this analysis. These include liquidity risk; interest rate risk and currency risk. The liquidity risk is low, since the peak observed in 2018 would be around USD 250 million (a projection), representing just under $30 \%$ of international reserves evaluated, at USD 844.82 million at the end of 2017.

With respect to interest rate risk, the portfolio has limited exposure to interest rate risk in that the floating fixed ratio informs a debt portfolio consisting entirely of fixed rate debt $(100 \%)$. The absence of variable rates means that the interest rate risk indicators are the same as the liquidity risk indicators, especially the average 9.21-year interest rate revision time, while the debt ratio to be revised in one year and five years are respectively $8.29 \%$ and $37.96 \%$. On the other hand, the portfolio carries a major currency risk in the sense that it is entirely denominated in foreign currencies. This reflects a worrying situation in the DRC's public debt portfolio.

\section{Conclusion}

The present work consisted of analyzing the sustainability of the DR Congolese public debt. To do this, the work was subdivided into four sections, the first dealing with the origin of DR Congolese debt, the second focusing on the PPTE initiative and the completion point, the third analyzing the 
Congolese debt portfolio. and the last two have analyzed both the sustainability of the public debt and the risks faced by the debt portfolio.

In the first section it was found that the problem of sustainability of the DRC's public debt dates back to the 1970 s and already during that time it was valued at a share of GDP equal to $90 \%$ of the GDP and a debt service ratio. $10 \%$ export. With rising Western interest rates and a predatory government, debt accumulated to $\$ 13$ billion in 2000 . As the country found itself in a situation of unsustainability and economic instability, it negotiated a total of 13 rescheduling to the completion point. The PPTE Initiative being addressed in the second section has allowed us to note that without this initiative the financial situation of the country would have deteriorated more and more. The analyzes made in the following sections have shown that since 2010 the DRC's debt has been maintained in the range of $\$ 6,000$ to $\$ 7,000$ million, most of which is due to external creditors. The debt sustainability analysis revealed that the debt remains viable, but the debt portfolio remains vulnerable to shocks to exports So, any action aimed at diversifying the economy would be able to maintain the sustainability of Congolese RD debt. The risk analysis revealed that all Congolese debt is denominated in foreign currency, which constitutes a significant currency risk.

\section{References}

[1] AfDB. Democratic Republic of Congo: Completion Point Document under the Enhanced PPTE Initiative. African development bank. (2011).

[2] DGDP. Statistical bulletin of the public debt. General Direction of Public Debt. (2010).

[3] DGDP. Statistical bulletin of the public debt. General Direction of Public Debt. (2011).

[4] DGDP. Statistical bulletin of the public debt. General Direction of Public Debt. (2012).

[5] DGDP. Statistical bulletin of the public debt. General Direction of Public Debt. (2013).

[6] DGDP. Statistical bulletin of the public debt. General Direction of Public Debt. (2014).

[7] DGDP. Statistical bulletin of the public debt. General Direction of Public Debt. (2015-2017).

[8] DGDP. Annual Report. General Direction of Public Debt. (2011-2017).

[9] IOB-SES. Evaluation of debt relief in the Democratic Republic of Congo. SES. (2012).

[10] OED. PPTE Initiative: Achievement and Prospects. World Bank. (2003). 